\title{
フレーム内アダマール変換直接符号化方式の諸特性
}

\author{
正会員 浜 田高 宏 ${ }^{\dagger}$, 正会員 松 本 修 一 ${ }^{\dagger}$, 正会員 村 上 仁 已
}

\section{Coding Performances of the Direct Composite Coding Scheme Based on Intraframe Hadamard Transform}

\author{
Takahiro Hamada $^{\dagger}$, Shuichi Matsumoto ${ }^{\dagger}$ and Hitomi Murakami ${ }^{\dagger}$
}

\begin{abstract}
Research and development is being widely conducted for DCT-based component TV signal coding The most dominant TV signal, however, is the composite TV signal transmitted from a TV studio to viewers. Here, a direct composite coding scheme with a coding performance equivalent to DCT-based component coding is necessary for preventing harmful effects on picture quality and additional hardwares by a separatıng and composing procedure for $\mathrm{Y} / \mathrm{C}$ components For this purpose, we have developed a direct composite codıng scheme based on intraframe Hadamard transform and optımızed parameters for essential techniques used in this scheme These include quantızatıon cube, framewise precoding, high-order coefficient truncation and adaptive scanning path selection This paper describes the coding performance for each optimized technique, as well as overall coding performance
\end{abstract}

\section{1. ま え がき}

近年，画像符号化に関する研究・開発が多くの機関 において活発に行われている。これらの活動のほとん どは，MPEGなどに代表されるようにコンポーネン 卜符号化を対象とし, DCT(離散コサイン変換)を基 本としたものである。しかしながら，放送スタジオか ら一般家庭まで配信されているテレビ信号はコンポジ ット信号であり,これにコンポーネントベースの DCT 符号化方式を適用するとなれば, 符号化の前後 に輝度／色差分離・合成処理が必要となり，この処理 に伴なう画質劣化, ハードウェアが大きな足かせとな る.このことから, 仮りにコンポーネント符号化と同
等の効率がコンポジット符号化で実現できれば，コン ポジット信号に対して極めて有利となるしかしなが ら, 直接符号化の研究・開発は，コンポジット信号特 有のカラーサブキャリヤ成分に起因する複雑な周波数 構造のためDCTを有効利用できず, 近年あまり活発 に行われていない そこで我々は, フレーム内アダマ ール変換を基本としたコンポジット (NTSC) 直接符号 化方式を考案し，コンパクトなハードウェア (MUCCS 45:45 Mb/s Multi-Channel TV Coding System)により実現した1)この文献では, 特定のテ ストデータに対しコンピュータシミュレーション実験 により有効性が示されているに過ぎず，あらゆる画像 データに対して有効性が示されているものではなかっ

キーワード：直接符号化，コンポジット信号，アダマール変換，フレーム单位固定ビット長化，量子化キューブ

1991 年 7 月 23 日, 1991 年テレビジョン学会年次大会で発表

1993 年 3 月 11 日受付, 1993 年 5 月 27 日再受付

$\dagger$ KDD 研究所 映像伝送グループ(テ356 埼玉県上福岡市大原 2-1-15, TEL 0492-66-7428)

$\dagger$ KDD R \& D Laboratories, Visual Communications Group (2-1-15, Ohara, Kamıfukuoka-shı, Saitama 356, Japan) 
た．その後，本符号化方式を構成している要素技術と して, 視覚特性を考慮した量子化キューブ, フレーム 単位プリコーティング＋高次係数切り捨てによるフ レーム単位固定ビット長化, 有効成分保存型適応スキ ヤニングなどのパラメータ最適化作業を実システムを 用いて詳細に行い, 各要素技術の符号化特性および方 式全体の総合符号化特性を文献 1)とも比較しながら 明らかにしたので, パラメータおよび各符号化特性の 詳細を本論文にて報告する。

\section{2. フレーム内アダマール変換直接符号化方式 の特徵および構成}

\section{1 万式の特徵}

コンポジット NTSC 信号の放送スタジオ局間素材 伝送を目的として, 本方式は以下の特徴を備えてい る。すなわち, 高能率符号化はもとより, 輝度/色差 分離に伴う劣化を避けるため直接符号化を行い, 圧縮 データのままでフレーム編集を可能とし，かつコンパ クトなハードウェアで構成可能とする。これらの特徵 を実現するための要素技術をまとめたのが表 1 であ る.

まず,アダマール変換はDCTよりもカラーサブキ ヤリヤ成分のパッキング効率に優れている(3.1節に て詳細説明). 次にハードウェアのコンパクト化拈よ びフレーム毎独立に圧縮データのままで編集作業など を可能とするため, 動き補償フレーム間処理は用い ず，フィールド間相関を用いたフレーム内処理にとど めることが望ましいと考えられる。ささらに，フレーム 単位の編集作業のためにはフレーム毎に一定のビット 長となる必要があり, そのために広く用いられている フィードバック型のポストバッファ制御の代わりに, あらかじめフレーム毎に発生情報量を予測し(プリコ ーディング), パラメータ制御を行い, 超過ビットに
対しては視覚的に重要でないものから切り捨てていく (非有意シフトダウン高次切り捨て方式) フィドーフォ ワード型の制御が有効である。また，人間の視覚特性 を充分考慮して量子化を行えば, 大きな効率改善が得 られる(量子化キューブ)。そしてコンポジットフレー ムにおける輝度成分, 色差成分およびインタレースに 伴うフィールド間動き成分は, アダマール変換上で 各々異なった位置にパッキングされる。これらの成分 を効率良く伝送するために, 有効成分保存型適応スキ ヤニングを用いている.

\section{2 方式の構成}

以上に基づき構成されたシステム, MUCCS 45 (外観写真 1) における符号化部のブロック図を示す (図 1).

まず, NTSC入力信号は入力部において $4 f_{s c}$ でサ ンプリングデータとなり, 水平 768 画素, 垂直 488 ラ インを有効データとして取り出しフィールドマージを 行う. 次に, $8 \times 8$ フレーム内アダマール変換を行い, $\mathrm{DC}$ 係数 ( 1 個), $\mathrm{SC}$ 係数 ( 2 個), $\mathrm{AC}$ 係数 (61 個)に 分類し, $\mathrm{DC}, \mathrm{SC}$ 係数は $\mathrm{DPCM}$ 部へ送る一方, $\mathrm{AC}$ 係数は，専用 LSI “Q-Cube” "2)3) (E-MODE : 符号化 モード)へ送る(外観写真 2)。なお，処理遅延のため には，1フレーム分のブリバッファが用意されてい る。

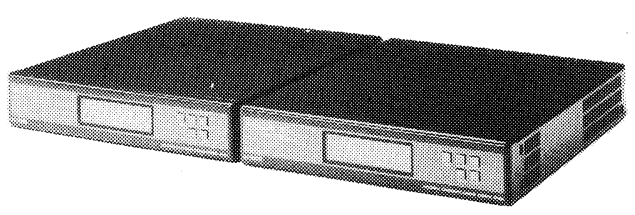

写真 1 NTSC 直接符号化システム (MUCCS 45)の 外観

External view of NTSC direct coding system. (MUCCS 45)

表 1 フレーム内アダマール変換直接符号化方式の特徴および要素技術

Distinctive features and essential techniques of direct composite coding scheme based on intraframe Hadamard transform.

\begin{tabular}{|c|c|c|c|c|c|}
\hline & アダマール変換 & $\begin{array}{l}\text { フレーム（フィールドマ } \\
\text { ージ）内処理 }\end{array}$ & $\begin{array}{l}\text { プリコーディング } \\
+ \text { 高次切捨 }\end{array}$ & 量子化キューブ & 適応スキャニング \\
\hline 直接符号化 & (C) & - & - & - & 0 \\
\hline $\begin{array}{l}\text { ハードウェア } \\
\text { コンパクト化 }\end{array}$ & $\triangle$ & () & $\triangle$ & - & - \\
\hline $\begin{array}{c}\text { 圧縮データにて } \\
\text { フレーム編集 }\end{array}$ & - & 0 & 0 & $\triangle$ & - \\
\hline 高能率化 & 0 & 0 & 0 & (O) & 0 \\
\hline
\end{tabular}

(C) : 非常に有効, $\bigcirc$ : 有効, $\triangle$ : やや有効, 一 : 特に関与せず 


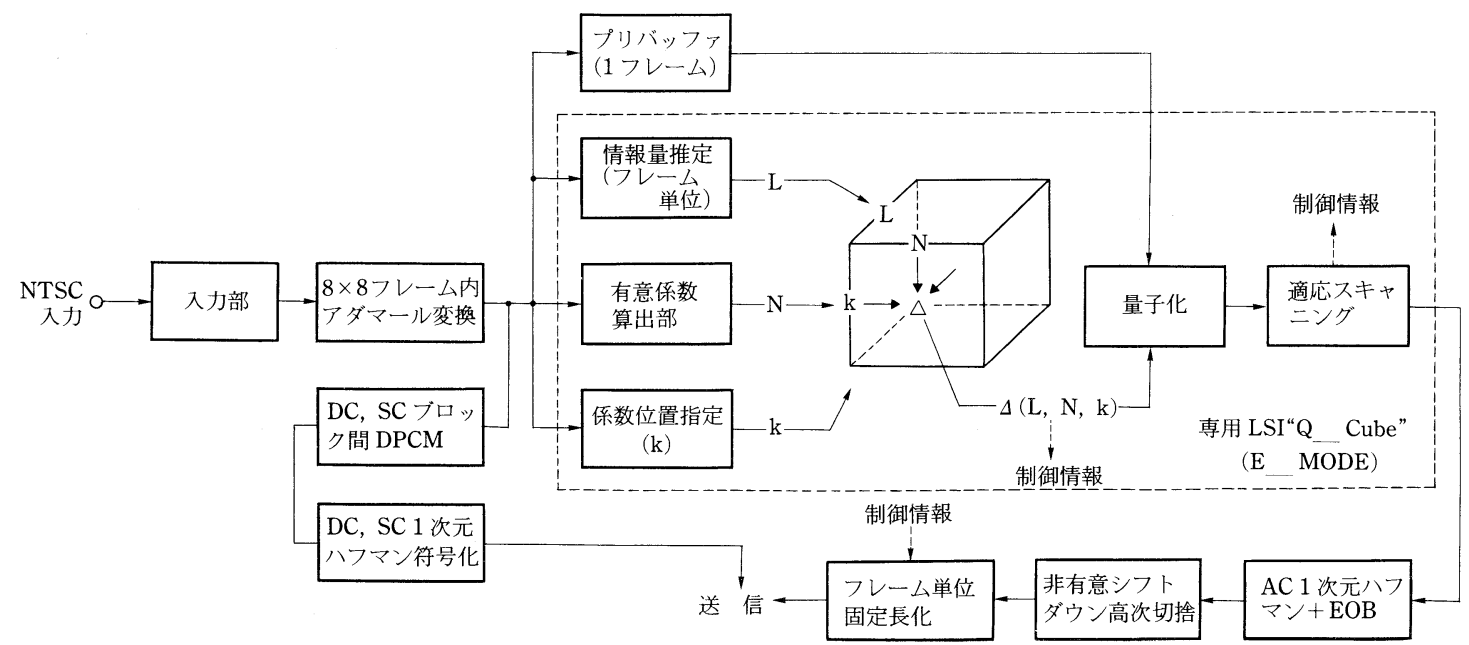

図 1 MUCCS 45 符号化部のブロック図 Block diagram of MUCCS 45 encoder.

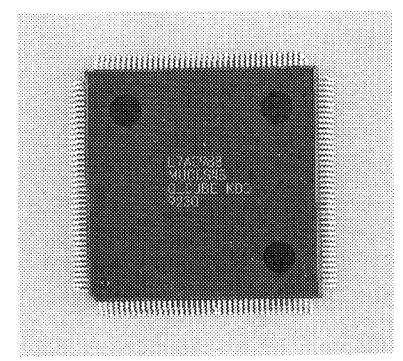

写真 2 主要圧縮部専用 LSI “Q-CUBE” Main coding ASIC " $\mathrm{Q}-\mathrm{CUBE}$ ”.

“Q-Cube” の内部で，1 フレーム分の $\mathrm{AC}$ 係数を仮 量子化 + 仮ハフマン符号化し情報量推定 $(L)$ を行 い, 画面全体の大局的な性質を把握する。また 32 画 素 $\times 8$ ラインのマクロブロック単位に, あらかじめ 定められた閾值を越える有意係数の個数 $(N)$ をカウ ントし, 局所的な絵柄の性質からくる雑音マスキング 効果の度合いを把握する。この $L, N$ および, 視覚 感度を反映した $\mathrm{AC}$ 係数の位置 $(k)$ の 3 次元パラメー 夕から量子化ステップサイズ $\Delta(L, N, k)$ を決定し, プリバッファから AC 係数を読出し, スケーリング手 法 + 丸め処理により量子化を行う(3.2 節にて詳細説 明). 量子化後の ACデータに対して, 伝送の順序を 示すスキャニングパターンが適応的に決定される，パ ターンの種類としては, 輝度成分 $(Y)$, 色差成分 $(C)$ およびインタレースにともなうフィールド間動き成分 $(M)$ を効率良く保存する 4 種類のパターンがあらか じめ準備されており, マクロブロック単位に最適スキ ヤニングパターンが 1 種類選択される (3.3 節にて詳
細説明)。

次に EOB(End of Block)制御のもとでハフマン符 号化される。 ハフマン符号化後のフレーム全体での情 報量は, フレーム単位のプリコーディング $(L)$ によ り，伝送レートから決まる1フレーム全体で許される ビット量にほぼ近い值となっているが, 正確に合わせ るため, ビット余りの時はスタッフビットを用い, 超 過ビットが生じる時には視覚的にそれほど重要でない 高次の $\mathrm{AC}$ 係数を順次切り捨てて, 発生ビットを所要 のビット量まで抑え込む. AC 係数の切り捨てにおい ては, EOB制御とのかね合いにより，より多くの非 有意係数 ( 0 代表値となる係数 $)$ を優先的に切り捨てる ことを目的として, 非有意シフトダウン高次切り捨て 方式を用いている(4.1節にて詳細説明). 切り捨て 後, フレーム単位に固定長化されたデー夕は, 量子化 器選択情報，スキャニングパターン選択情報などの制 御情報を付加し, 固定レートで伝送される. 量子化器 選択としては, フレームごとの情報量推定 $(L)$ によ り, あらかじめ準備されている 128 種類の量子化器セ ットの中から 1 セット選択し ( 7 ビット/フレーム), さらに量子化器セットごとに準備されている 4 種類の 量子化器のなかから, マクロブロックごとに有意係数 $(N)$ の值に応じて 1 種類選択する ( 2 ビット/マクロブ ロック).

復号部のブロック図を示す(図 2). 基本的には制御 情報をもとにし, 符号化部と逆の操作を行う. 受信デ 一夕を $\mathrm{DC}$ 係数, $\mathrm{SC}$ 係数, $\mathrm{AC}$ 係数およびその他の 制御情報に分類する. DC 係数, SC 係数には逆 $\mathrm{DPCM}$ を行い, $\mathrm{AC}$ 係数はハフマン $+\mathrm{EOB}$ 復号を 


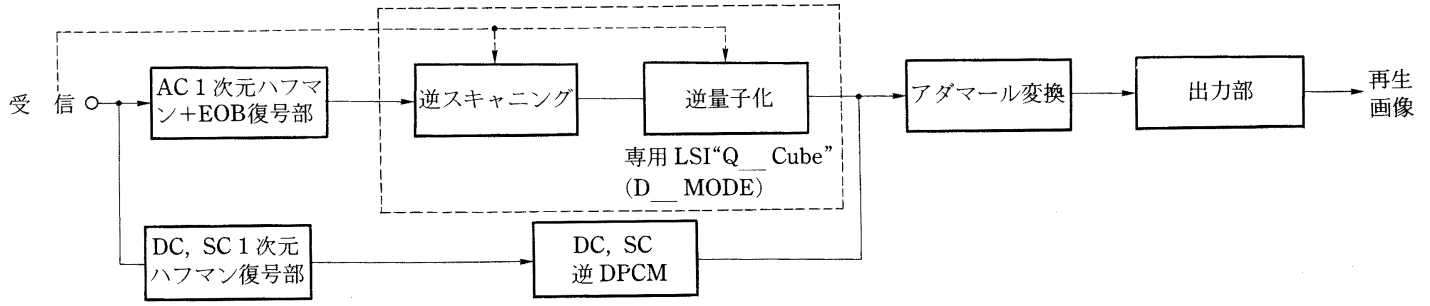

図 2 MUCCS 45 復号化部のブロック図 Block diagram of MUCCS 45 decoder.

行った後, 制御情報とともにQ-Cube (D-MODE：復 号化モード)へ入力する. 本 Q-Cubeでは, 逆スキャ ニングおよび逆量子化操作を行う。そして, 得られた $\mathrm{DC}, \mathrm{SC}, \mathrm{AC}$ 係数の再生值をもとにアダマール変換 を行い, NTSCとしての再生画像を得る.

なお，符号化レートとしては， $45 \mathrm{Mb} / \mathrm{s}$ (映像 39 $\mathrm{Mb} / \mathrm{s}$ )，22.5 Mb/s (映像 $18 \mathrm{Mb} / \mathrm{s}$ ), $15 \mathrm{Mb} / \mathrm{s}$ (映像 $12 \mathrm{Mb} / \mathrm{s}$ )，11 Mb/s(映像 $9 \mathrm{Mb} / \mathrm{s}$ )の 4 種類を持つ.

\section{3. 各要素技術の符号化特性}

\section{1 フレーム内アダマール変換}

まず，NTSC 直接符号化の有効性を示すため，輝 度／色差分離・合成を行うことによる劣化の度合いを 定量的に明らかにする. CCIRのテストデータ (Mobile \& Calendar, Flower garden およびBoat)を D 2 (コンポジット信号)に変換したものを原画とし, ディジタルカラーデコーダ・エンコーダを通し，一度 輝度／色差分離・合成を行った画像 (D 2) を原画と比較 して得られる $\mathrm{SNR}(S=255 \times 0.7)$ および主観的な劣 化度(原画の画質を $100 \%$ とした時，テスト画像の劣 化の度合いを 0 ～100\%で示したもの．5段階評価で 1 ポイントは約 $24 \%$ に相当する) を求めた(表 2 )。な お,ディジタル色分離・合成には, ライン間・フレー 厶間適応 3 次元処理による市販の機器を用いた。また 表 2 に扔いて, 主観評価は CCIR 勧告 500-5 に準拠し て行った ${ }^{4)}$. 専門家による評価は, 非専門家の評価に 対して約 $1 \%$ 劣化度が大きくなる傾向がみられたが， いずれにしても，スタジオ局間素材伝送品質が最悪 $12 \%$ という規格を考慮すると, 輝度/色差分離に伴う 劣化は大きな足かせであることが理解できる．

次にディジタル圧縮のための方式であるが, 現在最 も広く用いられているDCTをコンポジット信号 (NTSC)に適用すると, 色差信号変調のための 3.58 $\mathrm{MHz}$ カラーサブキャリヤ成分 (SC成分)が, 図 3 に 示されるように 20 個の係数に分散する(他の 44 係数 は零となる). SC 成分は色信号保存の観点から歪み
表 2 輝度/色差分離・合成に伴う画質劣化 Degradation by $\mathrm{Y} / \mathrm{C}$ separation-composing.

\begin{tabular}{c|c|c}
\hline \hline テストデータ名 & SNR $(\mathrm{dB})$ & $\begin{array}{c}\text { 主観的な劣化度 } \\
(\%)\end{array}$ \\
\hline Mobile \& Calendar & 37.4 & $7 \sim 8$ \\
\hline Flower garden & 41.0 & $3 \sim 4$ \\
\hline Boat & 41.1 & $3 \sim 4$ \\
\hline
\end{tabular}

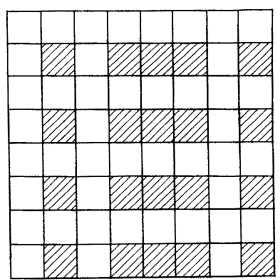

$8 \times 8$ フレーム内 DCT

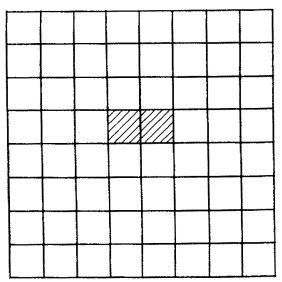

$8 \times 8$ フレーム内 WHT

図 $3 \mathrm{SC}$ 成分の係数位置の比較 Comparison of coefficient location of SC components.

をほとんど許容できず，DCT を直接 NTSC に適用す る場合, 効果的な圧縮は期待できない。一方, アダマ 一ル変換を用いた場合, SC 成分は 2 個の係数のみに 効果的にパッキングされ, 周波数構造の観点からも NTSC 本来の形に近い構造となり, 効果的な圧縮が 期待し得る5)。また，NTSC はインタレース構造をと る関係上, 直交変換を行うためのブロックの作り方と して, フィールド内処理拉よびフィールドマージに基 づくフレーム内処理が考えられる. 図 4 に数種類のテ スト画像に扔ける両者の 1 フレームにわたる符号化特 性の比較を示す．図中，SNRで $S$ はフレーム内での 交流係数のパワー平均を示し, 両者にとって共通であ る.すなおち，画素当たりの歪み量が小さい方が，よ り高いSNR となる。 また，量子化操作は係数位置に よらず, 一律のステップサイズによる線形量子化器を 用いた．用いたテスト画像はいずれもズーム, パンニ ングなどの動きを伴う画像であるものの, フレーム内 

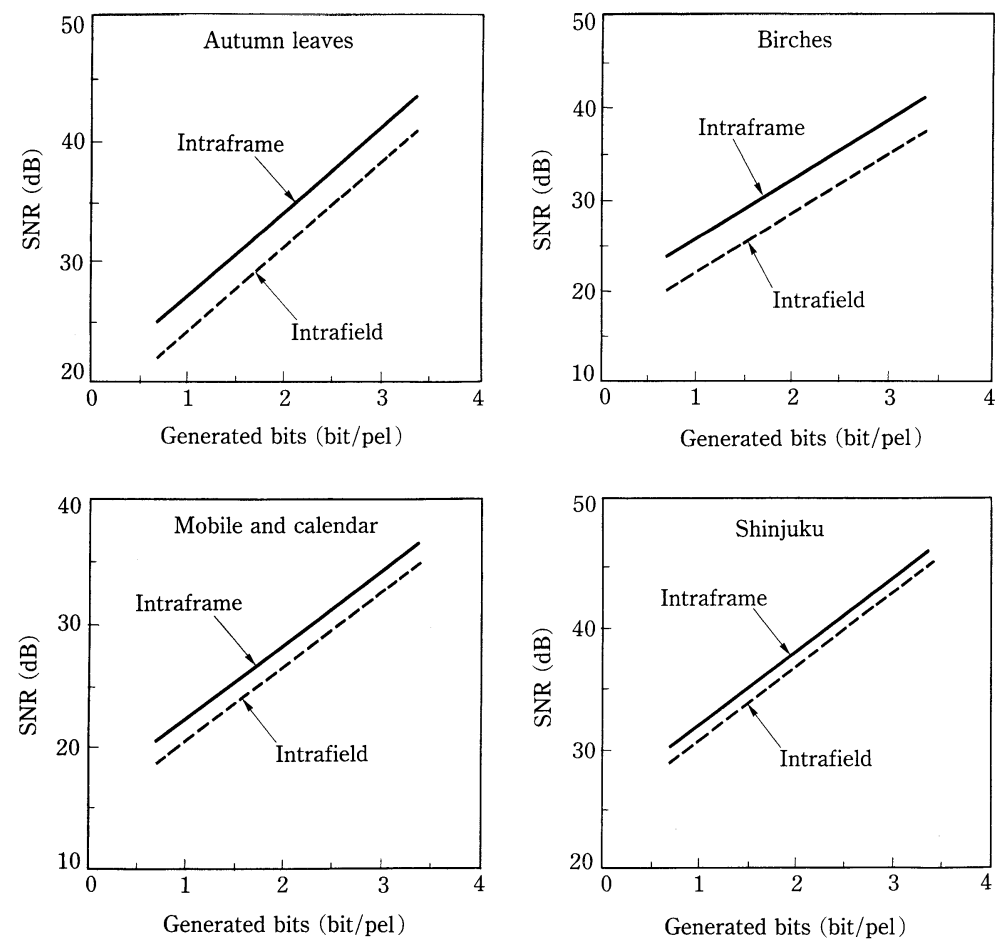

図 4 フレーム内/フィールド内アダマール変換の効率比較

Efficiency comparison of intraframe/intrafield Hadamard transform.

処理の方が符号化効率が高い $(2 \sim 3 \mathrm{~dB})$. このことか ら，フレーム内処理を用いることの有効性が理解でき る。

\section{2 視覚特性を考慮した量子化キューブ}

画像符号化において，考慮すべき重要な視覚特性と しては次の 2 種が考えられる.

（1）空間周波数方向の視覚特性(より高周波の雑音 ほど検知されにくい)

(2) 雑音マスキング効果 (より激しく変化している ブロックで発生する雑音ほど検知されにくい)

(1) はアダマール変換係数位置に依存する. 文献 1) においては，動きが少なく色差成分が低周波だけ に限られる画像を想定して変換係数のクラスタを得て いた。しかしながら，実システム上で 64 個のアダマ 一ル変換係数を, 1 係数ずつ切り捨てた場合の各々の 劣化度を CCIR Rec. 500-5 に準拠した形で求めたとこ 万, 輝度成分の劣化以外に, $\mathrm{SC}$ 成分のまわりの 6 個 の係数に視覚的に重要な色差高周波成分が発生し，ま た垂直最高次係数(左下の係数)を含め，そのまわりの 6 個の係数に視覚的に重要なフィールド間動き成分が 存在することが明らかになった。そこで, 劣化の種類 を輝度，色差および動きの観点から 3 種類に分類し， それぞれにおいて, 係数切り捨てによりほほ等しい劣

\begin{tabular}{|c|c|c|c|c|c|c|c|}
\hline $\mathrm{DC}$ & $\mathrm{Y} 1$ & $\mathrm{Y} 2$ & $\mathrm{Y} 3$ & $\mathrm{Y} 4$ & $\mathrm{Y} 4$ & $\mathrm{Y} 5$ & $\mathrm{Y} 5$ \\
\hline $\mathrm{Y} 1$ & $\mathrm{Y} 2$ & $\mathrm{Y} 3$ & $\mathrm{Y} 5$ & $\mathrm{C} 3$ & $\mathrm{SH} 1$ & $\mathrm{SH} 1$ & $\mathrm{SH} 2$ \\
\hline $\mathrm{Y} 2$ & $\mathrm{Y} 3$ & $\mathrm{Y} 5$ & $\mathrm{C} 2$ & $\mathrm{C} 1$ & $\mathrm{C} 3$ & $\mathrm{SH} 2$ & $\mathrm{SH} 2$ \\
\hline $\mathrm{Y} 3$ & $\mathrm{Y} 5$ & $\mathrm{C} 2$ & $\mathrm{SC} 1$ & $\mathrm{SC} 2$ & $\mathrm{C} 1$ & $\mathrm{SH} 2$ & $\mathrm{SH} 2$ \\
\hline $\mathrm{Y} 4$ & $\mathrm{SH} 1$ & $\mathrm{SH} 1$ & $\mathrm{SH} 1$ & $\mathrm{SH} 2$ & $\mathrm{SH} 2$ & $\mathrm{SH} 2$ & $\mathrm{SH} 2$ \\
\hline $\mathrm{Y} 4$ & $\mathrm{SH} 1$ & $\mathrm{SH} 1$ & $\mathrm{SH} 2$ & $\mathrm{SH} 2$ & $\mathrm{SH} 2$ & $\mathrm{SH} 2$ & $\mathrm{SH} 2$ \\
\hline $\mathrm{M} 1$ & $\mathrm{M} 2$ & $\mathrm{SH} 2$ & $\mathrm{SH} 2$ & $\mathrm{SH} 2$ & $\mathrm{SH} 2$ & $\mathrm{SH} 2$ & $\mathrm{SH} 2$ \\
\hline $\mathrm{M} 1$ & $\mathrm{M} 1$ & $\mathrm{M} 2$ & $\mathrm{M} 2$ & $\mathrm{SH} 2$ & $\mathrm{SH} 2$ & $\mathrm{SH} 2$ & $\mathrm{SH} 2$ \\
\hline
\end{tabular}

図 5 アダマール変換係数のクラスタリング Classification of WHT coefficients.

化度を与える係数をまとめて 1 種類のクラスタとし， 図 5 を得た。そして各クラスタごとに, 線形量子化を 行い, 互いにほぼ同程度の主観的劣化度を与える雑音 電力量をそれぞれ求め, 各々のクラス夕に含まれる係 数の個数で除したものの平方根の相対比率の逆数を, 雑音の視覚感度 (表 3)として得た。

(2) はブロック内 $\mathrm{AC}$ 係数パワーに依存し6)，AC 係数のパワーの大小を簡易なハードウェアで把握する 方式として, 各 AC 係数の絶対值を, あらかじめ定め られた閾值(係数の位置によらず一律 5 ) と大小比較 し, 閾值を越える係数を有意係数としてマクロブロッ ク単位に数え上げる方式を用いた。閾值を 5 と設定し 
表 3 各クラスタリングにおける視覚感度

Relative sensitivity on each classification.

\begin{tabular}{c|c|c}
\hline \hline クラスタ & 信号の性質 & 視覚感度 \\
\hline $\mathrm{Y} 1$ & 輝度第 $1 \mathrm{AC}$ 係数 & 1.00 \\
\hline $\mathrm{Y} 2$ & 輝度第 $2 \mathrm{AC}$ 係数 & 0.75 \\
\hline $\mathrm{Y} 3$ & 輝度第 $3 \mathrm{AC}$ 係数 & 0.60 \\
\hline $\mathrm{Y} 4$ & 輝度第 $4 \mathrm{AC}$ 係数 & 0.50 \\
\hline $\mathrm{Y} 5$ & 輝度第 $5 \mathrm{AC}$ 係数 & 0.40 \\
\hline $\mathrm{C} 1$ & 色差第 $1 \mathrm{AC}$ 係数 & 0.75 \\
\hline $\mathrm{C} 2$ & 色差第 $2 \mathrm{AC}$ 係数 & 0.60 \\
\hline $\mathrm{C} 3$ & 色差第 $3 \mathrm{AC}$ 係数 & 0.30 \\
\hline $\mathrm{M} 1$ & 動き第 $1 \mathrm{AC}$ 係数 & 0.75 \\
\hline $\mathrm{M} 2$ & 動き第 $2 \mathrm{AC}$ 係数 & 0.50 \\
\hline $\mathrm{SH} 1$ & 第 1 超高 $\mathrm{AC}$ 係数 & 0.30 \\
\hline $\mathrm{SH} 2$ & 第 2 超高 $\mathrm{AC}$ 係数 & 0.15 \\
\hline
\end{tabular}

たのは，この時の有意係数の総数とブロック内 $\mathrm{AC}$ 係 数パワー総和の相関が最も高かったためである。そし て，符号化雑音の検知の度合いの観点から，画像の局 所的絵柄として，空などの平坦部，人間の肌などのな だらかな変化部，文字などのエッジ部および森や林な
表 4 雑音マスキング効果を考慮したマクロブロックの分類 Macroblock clasification considering noise masking effect.

\begin{tabular}{c|c|c}
\hline \hline 有意係数の総数 & 局所的性質 & 視覚感度 \\
\hline $0 \sim 20$ & 平坦部 & 1.00 \\
\hline $21 \sim 50$ & なだらかな変化部 & 0.79 \\
\hline $51 \sim 85$ & エッジ & 0.69 \\
\hline $86 〜 244$ & 精細部 & 0.55 \\
\hline
\end{tabular}

どの精細部の 4 種類のマクロブロック分類を考え, 数 種類のテスト画像を用いてこれらの分類を最も正確に 反映する有意係数の総数を実験により探し出し, 各分 類における雑音電力の平方根からの逆数から相対感度 を表 3 と同様の手法により得た(表 4)．最終的な雑音 の視覚感度は表 3 に表 4 を乗じることにより得られ る.

表 3 および表 4 から得られる視覚感度による雑音の 重みづけの観点から，与えられた入力画像に対して重 みづけ雑音の総和を最小とする量子化器の設計手法は すでに求められている6 . 本手法を用いて最適設計さ れた量子化器と, 視覚特性を考慮せず係数によらず一 律のステップサイズの量子化器との符号化特性の比較 が図 6 である。図中 WPSNR では，S=255×0.7,N
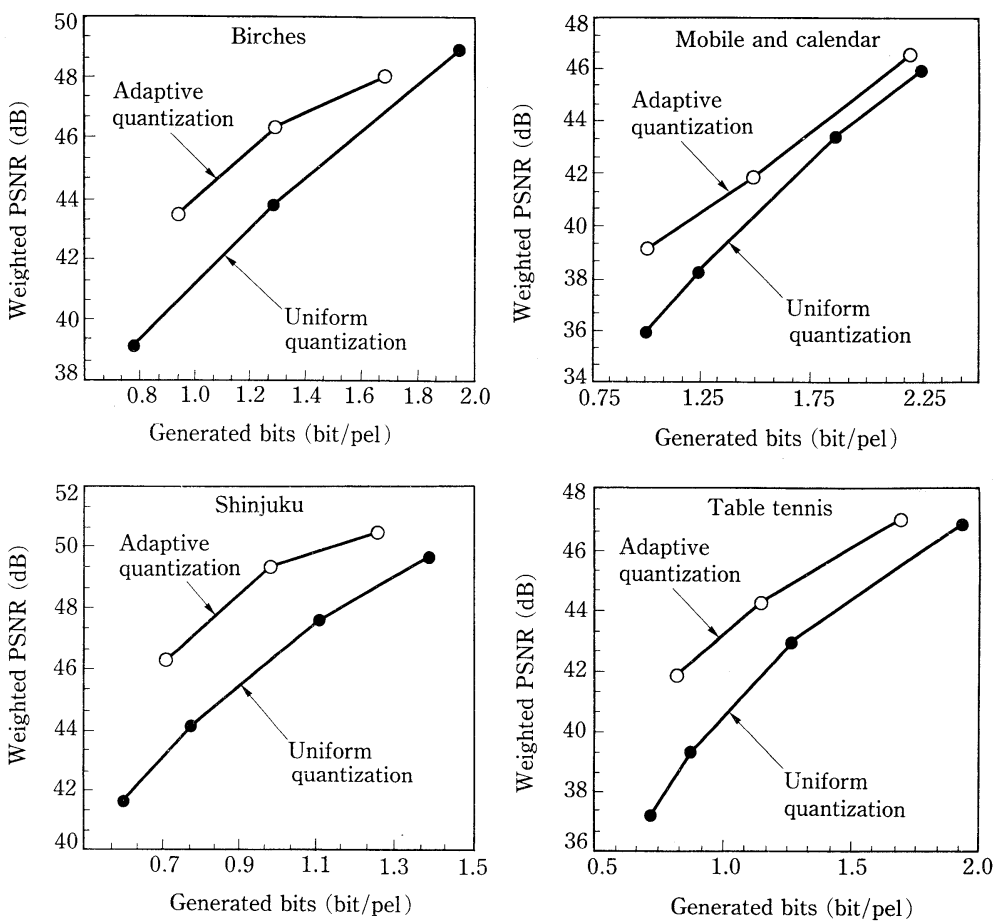

図 6 視覚特性を考慮した量子化キューブの符号化利得

Coding gain of quantization cube considering human visual perception. 


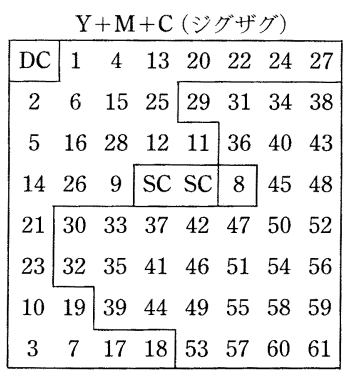

\begin{tabular}{|c|cccccccc|}
\multicolumn{8}{|c}{$Y+M$ (垂直) } \\
DC & 1 & 4 & 9 & 16 & 18 & 20 & 23 \\
\hline 2 & 6 & 11 & 21 & 49 & 47 & 43 & 41 \\
5 & 12 & 24 & 25 & 26 & 45 & 39 & 37 \\
10 & 22 & 27 & SC & SC & 28 & 46 & 51 \\
17 & 29 & 30 & 32 & 48 & 42 & 40 & 53 \\
19 & 31 & 33 & 34 & 44 & 38 & 36 & 56 \\
8 & 15 & 35 & 50 & 52 & 55 & 58 & 59 \\
3 & 7 & 13 & 14 & 54 & 57 & 60 & 61 \\
\hline
\end{tabular}

\begin{tabular}{|c|cccccccc|}
\multicolumn{8}{|c|}{$Y+C$ (水平) } \\
\hline DC & 1 & 4 & 11 & 15 & 17 & 19 & 22 \\
\cline { 1 - 5 } 2 & 6 & 13 & 20 & 29 & 30 & 32 & 33 \\
5 & 14 & 23 & 10 & 9 & 31 & 34 & 35 \\
12 & 21 & 8 & SC & SC & 7 & 46 & 51 \\
16 & 49 & 47 & 43 & 48 & 42 & 40 & 53 \\
18 & 45 & 41 & 39 & 44 & 38 & 36 & 56 \\
27 & 24 & 37 & 50 & 52 & 55 & 58 & 59 \\
3 & 28 & 26 & 25 & 54 & 57 & 60 & 61 \\
\hline
\end{tabular}

\begin{tabular}{|c|cccccccc|}
\hline DC & 1 & 4 & 7 & 11 & 13 & 15 & 18 \\
\cline { 1 - 5 } 2 & 6 & 9 & 16 & 48 & 46 & 42 & 40 \\
5 & 10 & 19 & 23 & 24 & 44 & 38 & 36 \\
8 & 17 & 26 & SC & SC & 27 & 30 & 51 \\
12 & 49 & 47 & 43 & 29 & 32 & 33 & 53 \\
14 & 45 & 41 & 39 & 31 & 34 & 35 & 56 \\
25 & 20 & 37 & 50 & 52 & 55 & 58 & 59 \\
3 & 28 & 22 & 21 & 54 & 57 & 60 & 61 \\
\hline
\end{tabular}

図 7 有効成分保存型適応スキャニング

Adaptive scanning path selection preserving significant components.

= 発生した雑音を表 $3 \times$ 表 4 の視覚感度により重み づけしたものを用いている。この図から, 量子化器を 最適化することによる視覚的な特性改善効果は極めて 大きい $(2 \sim 4 \mathrm{~dB})$ ことが理解できる.

\section{3 有効成分保存型適応スキャニング}

一般に，コンポーネントDCT 符号化などにおいて は，エッジの方向性の観点から高次係数の電力分布に は偏りが生じる。このことを考慮し, 文献 1 )ではエ ッジの方向性だけを考慮した適応スキャニング(ジグ ザグ, 垂直, 水平, 斜め)が行われていた。一方, NTSCをフレーム内アダマール変換した場合, 電力 分布の偏り以外に図 5 で示されるように, 輝度 $(Y)$, 色差 $(C)$, フィールド間動き $(M)$ 成分は各々離れた 位置でパッキングされる。したがって，これらの有効 成分を効果的に保存することがより重要であるため, 4 種類のスキャニングパターンとして,$Y+M+C$ (ジグザグ),$Y+M$ (垂直),$Y+C$ (水平),$Y$ (な なめ)をあらかじめ準備し(図 7)，この中から最適の スキャニングパターンをマクロブロック単位に選択す る適応スキャニング方式を最適パラメータとして得 た。すなわち，低レートの符号化時 $(9,12 \mathrm{Mb} / \mathrm{s}) て ゙$ は, 解像度をある程度犠牲にしても, 量子化雑音を低 減させるため, NTSC 信号の帯域として $4.2 \mathrm{MHz}$ 程 度の帯域までを保存することを目的とし，アダマール 変換上でこの保存带域に相当する係数として $\mathrm{Y} 1 \sim \mathrm{Y} 5, \mathrm{C} 1, \mathrm{C} 2, \mathrm{M} 1, \mathrm{M} 2$ (全部で 28 係数)だけ
を符号化の対象とし，それ以外のC $3, \mathrm{SH} 1, \mathrm{SH} 2$ は常時切り捨てることとする.これらの $1 \sim 28$ 係数 の中で $\mathrm{EOB}$ の位置が最も小さくなるスキャニングパ ターンを $Y+M+C, Y+M, Y+C, Y$ の中から 選択する。また $18 \mathrm{Mb} / \mathrm{s}$ 以上の符号化時には低レー トで適応的に保存する必要のある 28 個の係数は, 常 時保存可能となり, さらに高解像度化を考慮し C 3 , SH 1, SH 2 を加え, 1 61 の係数の中で $\mathrm{EOB}$ の位 置が最も小さくなるスキャニングパターンを, ジグザ グ, 垂直, 水平, 斜めの中から適応選択し, 低レート

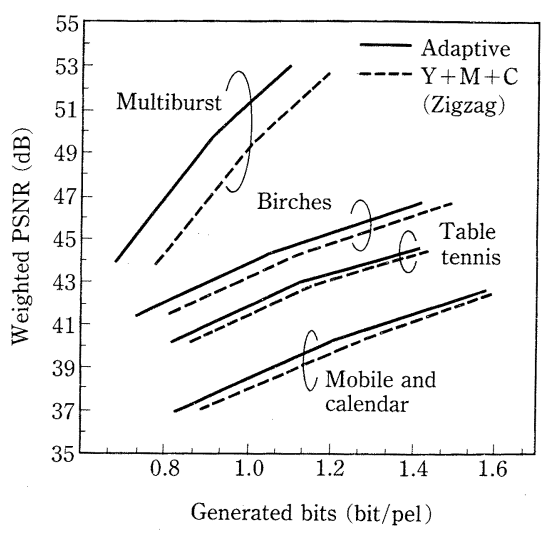

図 8 有効成分保存型適応スキャニングによる符号化 利得

Coding gain of adaptive scanning path selection with significant components preservation. 
と高レートで適応保存の対象係数が異なる 2 重構造の 適応スキャニング方式をなす。

図 8 に適応スキャニングと, 単一の固定スキャニン グでは最も効率の高い $Y+M+C$ (ジグザグ)パター を用いた場合との符号化利得の比較を示す。この図か ら, 低レートの符号化となるにつ特性は向上し, 自 然画像では $1 \mathrm{~dB}$ 程度, マルチバーストなどのように 人工的な画像では $2 \sim 3 \mathrm{~dB}$ 程度の WPSNR 改善効 果が得られており, 適応スキャニング方式により圧縮 効率が高められていることが理解できる.

\section{4. 総合符号化特性}

本章では, フレーム内アダマール変換直接符号化方 式の総合符号化特性として, プリコーディング-非有 意シフトダウン高次切り捨て処理による, フレーム単 位固定ビット長化における符号化制御の精度, および 本方式により得られる再生画像に対する主観評価值の 時間発生率について明らかにする。

\section{1 フレーム単位固定ビット長化における符号化 制御の精度}

プリコーディングで得られる1フレーム全体の推定 情報量 $(L)$ に基づいた符号化により, 発生情報量は ほぼ1フレームで許されるビット量となるように量子 化制御が行われているが, 超過ビットに対しては, 非 有意シフトダウン高次係数切り捨て方式により対処す る。

本切り捨て方式の概念を, 文献 1)に打いて用いら れていた方式(図中左側) と共に図 9 に示す。フレーム 内の各ブロックの係数をスキャニング順に並べる。ブ ロック 1 は画面左上端, ブロック $\mathrm{M}$ は画面右下端に 位置し, 視覚的により重要度が低い高次の係数から 1 係数/ブロックずつブロック 1 から切り捨てて行くこ とを基本とする. 有意係数は 2 ビット, 非有意係数は 1 ビットの符号長を持つものとし, 画面全体で 8 ビッ トの超過ビットが存在するものと仮定する．図 9 の左 側に示されるように, 単純に切り捨てて行く場合(文 献 1 )に扔いて用いられていた方式)，有意係数が 4 係 数も切り捨てられ大きな画質劣化となる.一方，右側 に示されるように，非有意係数 1 個当たり， 1 次シフ トダウンして行き, より多くの非有意係数を抱えてい る有意係数が切り捨てられる優先度を高くすると, $\mathrm{EOB}$ 制御の点から効果的に超過ビット切り捨てが実 現可能となる．実際このモデル図において，2 個の有 意係数の損失で切り捨てが終了することとなる。な お，当然のことながら非有意係数は切り捨てられても 画質劣化は生じない.

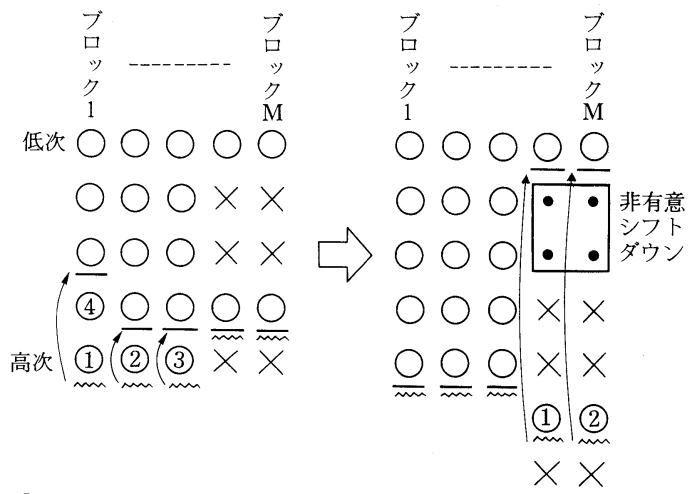

$\bigcirc$ : 有意俰数 ( 2 ビット, 中の数字は切り捨てられる順番を示す) X : 非有意俰数 ( 1 ビット)

m : 切り捨て前の $\mathrm{EOB}$ 位置, 一：切り捨て後の EOB 位置

図 9 非有意シフトダウン高次係数切り捨て方式の概念 Concept of high order coefficients' truncation with non-significant coefficients shifted down.

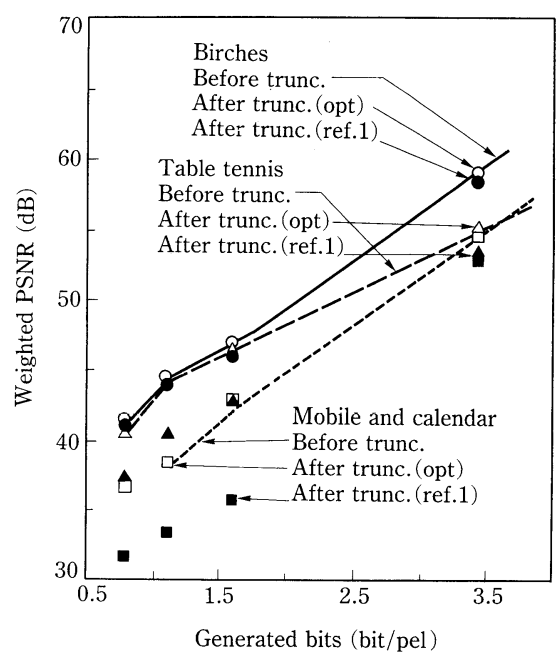

図 10 高次係数切り捨てに扔ける符号化特性 Coding performance for high order coefficients truncation.

本方式を用いたフレーム単位固定ビット長化におけ る符号化制御の精度を定量的に示すため, テスト画像 に対し, $39 \mathrm{Mb} / \mathrm{s}, 18 \mathrm{Mb} / \mathrm{s}, 12 \mathrm{Mb} / \mathrm{s}, 9 \mathrm{Mb} / \mathrm{s}$ 符号 化時, 切り捨て前・後における符号化特性を示したの が図 10 である. 切り捨て後の符号化特性(プロット： After trunc. (opt)) は，ほぼ切り捨て前の速度一歪み曲 線上(Before trunc.)に存在し, 固定ビット長化とい う制約による符号化口スはほとんどなく，精度良く符 号化制御が実現されていることが理解できる.

また同時に, 量子化キューブ, 高次係数切り捨て, 適応スキャニングなどのパラメータとして文献 1)の ものを用いた場合の特性も同時に示す (After trunc. 


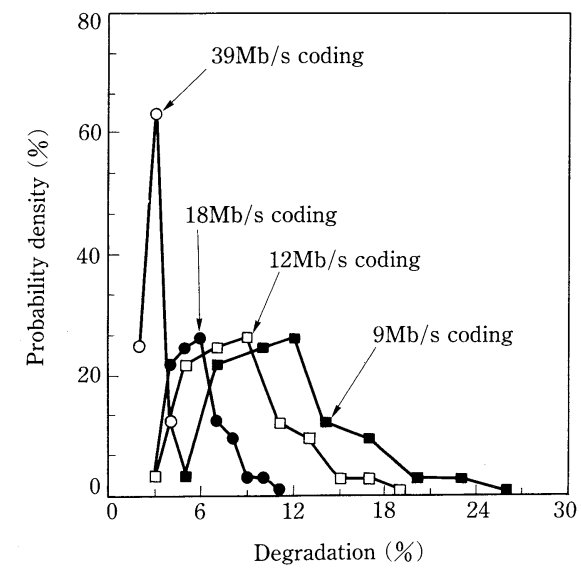

図 11 再生画像に扔ける主観評価值の発生確率

Subjective evaluation value of coded images v.s. probability density on time scale.

(ref.1)). 図中 Birches は文献 1)においても用いら れたテストデータであり, 適応スキャニングのパラメ 一夕が不充分であるため $0.5 \sim 1 \mathrm{~dB}$ 程度の符号化口 スがみられるだけである。一方, 今回新しく用いた Table tennis, Mobile and calendarでは, 動き量が 大きく, 色差高周波成分も多く含まれているため, こ れらを考慮していない文献 1)のパラメータでは, 評 価 SNRで 3〜 $7 \mathrm{~dB}$ と大きな劣化をまねくこととな り，実システムを用いて最適化した意義が理解でき る.

\section{2 再生画像における主観評価値の発生確率}

MUCCS 45 においては，1フレーム分の AC 係数 を仮量子化十ハフマン符号化し, 発生ビットの総和 を $2^{12}$ により除した值 $(L)$ がフレーム単位にリアル夕 イム出力される。この $L$ の值が大きいほど精細部分 をより多く持つ，いわゆる圧縮の困難な画像である. この機能を利用し, 一般的に用いられているテスト画 像や放送局オンエア信号を用い，Lの発生頻度 (時間 率)を測定し，また各 $L$ における代表的なテス卜画像 に対し主観評価を行い，これらから主観評価值の発生 確率を求めた。これを図 11 に示す。この図から，18 $\mathrm{Mb} / \mathrm{s}$ の符号化においては, 最悪值が劣化度 $12 \%$ (MOS 5 段階評価値で 4.5) 以下(以上)となり, 局間 素材伝送品質を満足し得る。また $12 \mathrm{Mb} / \mathrm{s}$ 符号化で は最悪值が劣化度 $18 \%(4.0)$ 程度となり, 番組 2 次分 配品質を満足し得る. $9 \mathrm{Mb} / \mathrm{s}$ 符号化では, 入力画像 の約 $80 \%$ が $18 \%$ (4.0) 以下(以上)を満足し得ることと なり, 入力ソースの種類の観点から, VHS, $\beta$-Cam
ソースなどに対して, 番組 2 次分配品質を満足し得る こととなる．

\section{5.むす び}

コンポジット信号の直接符号化, フレーム単位固定 ビット長化を特徵とする, フレーム内アダマール変換 直接符号化方式における諸特性を明らかにした。その 結果, $22.5 \mathrm{Mb} / \mathrm{s}$ (映像分 $18 \mathrm{Mb} / \mathrm{s}$ 程度) の伝送レート でNTSC を局間素材伝送品質で, $11 \sim 15 \mathrm{Mb} / \mathrm{s}$ (映像 分 $9 \sim 12 \mathrm{Mb} / \mathrm{s}$ 程度)の伝送レートでNTSC を番組 2 次分配品質で伝送可能であることが明らかになった。

今後の課題としては, 本方式を繰り返し実行した場 合の符号化特性や，伝送路で発生する誤りに対する耐 久力を明らかにして行くことである。

\section{〔参 考 文 献〕}

1) S. Matsumoto, T. Hamada, M. Saito and H. Murakami : "45 Mbps Multi-Channel Composite TV Coding System", IEICE Trans. Commun., E75-B, 6, pp. 358-367 (May 1992)

2) 浜田, 松本 : “直交変換符号化用適応量子化 LSI [Q-CUBE」 の開発”, 第 2 回ハイビジョン研究会, 2-3, pp. 39-44 (Sep. 1992)

3）浜田, 松本： “コンポジットTV 信号符号化用 LSI チップ 「量子化キューブ」の開発”, 画像符号化シンポジウム (PCSJ) , 3-3, pp. 109-112 (Oct. 1992)

4) CCIR Recommendation 500-5: "Method for the Subjective Assessment of the Quality of Television Pictures", pp. 166-189 (Sep. 15, 1992)

5）松本, 浜田, 斉藤 : “直接符号化におけるDCT とアダマー ル変換の符号化効率比較”, 平 2 信学秋季全大, D-187

6）浜田, 松本：“画像の局所的変化度による雑音マスキング効 果を慮した直交変換係数の最適量子化法”, 信学論, J75-B - I , 12, pp. 791-801 (Dec. 1992)

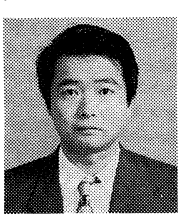

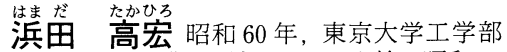
電気工学科卒業. 同年, KDD 入社. 昭和 62 年より KDD 研究所勤務. 以来, HDTV, EDTV, 放送級テレビ信号などの高能率符 号化简する研究・開発に従事. その間, 米 国カリフォルニア工科大学より MS 取得 (電 気工学, 平 1 ). 現在, 同研究所映像伝送グ ループ担当主査. 正会員.

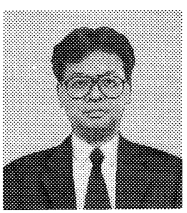

松本 修一昭和 54 年, 北海道大学大学 院修士課程修了. 同年, KDD 亿入社. 以 来, 研究所にて, HDTV, SDTVの高能率 符号化方式の研究・開発に従事. 現在, 同所 映像伝送グループ主任研究員. 工学博士. 正 会員.

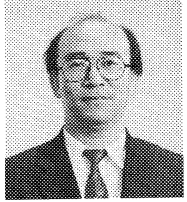

村上 仁壁 昭和 49 年, 北道大学大学院 博士課程修了. 同年, KDD $に$ 入社. 研究所 にて, ディジタル衛星通信方式, 画像高能率 符号化方式の研究に従事. 現在, 同研究所次 長. 工学博士. 正会員. 